УДК 904:72 (477.82) «09/17»

БУРАКОВ Ю.В.

https://orcid.org/0000-0001-7180-4469

https://doi.org/10.33577/2313-5603.34.2020.245-250

\title{
СТОЛИЦЯ ГАЛИЦЬКО-ВОЛИНСЬКОЇ ДЕРЖАВИ У СВІТЛІ АРХЕОЛОГІї
}

Терський С.В. Археологія міста Володимира. Володимир-Волинський; Новоград-Волинський: Видавництво «Новоград», 2020. 244 с.

Одним із найбільш складних i одночасно цікавих питань історичної науки є походження та розвиток торгово-економічних, політичних i культурних центрів Давньоукраїнської держави, а саме міст. Давньоукраїнські міста належать до найважливіших поселень, що займали значну територію і мали складну територіальну структуру та фортифікаційну систему.

Проблема їхнього походження, соціальної суті і структури віддавна привертає увагу вітчизняних i зарубіжних науковців, оскільки міста були опорними пунктами, соціально-економічними, політичними та культурно-освітніми центрами як окремих удільних князівств, так і Давньоукраїнської держави в цілому. У них відбувалося формування нових феодальних станів, нових форм господарсько-виробничої діяльності. Тут зосереджувалися князівська адміністрація, вільні ремісники та купці. При спробі простежити і зрозуміти процес становлення давньоукраїнського міста дослідники натрапляють на певні труднощі, оскільки недостатньою $є$ кількість писемних джерел та археологічних матеріалів. Окрім того, залишається низьким рівень теоретичної розробки проблеми. Ще більш ускладнюється питання при визначенні місця ремісничого посаду у процесі виникнення i формування міста.

Вивчення соціально-економічного, політичного та культурного розвитку давньоукраїнських міст займає важливе місце у вітчизняній історіографії. С.В. Терський присвятив цьому питанню низку своїх монографій та наукових статей, де детально описано

Бураков Юрій Васильович, кандидат історичних наук, доцент, провідний науковий співробітник Наукового центру Сухопутних військ Національної академії сухопугних військ імені гетьмана Петра Сагайдачного, м. Львів.

(С) Бураков Ю.В., 2020 
топографію, оборонне значення, різні елементи військової інфраструктури таких літописних центрів Галицько-Волинської держави, як Львів, Лучеськ, Пересопниця, Перемишль, Чемерин та інших.

Повідомлення писемних джерел та археологічний матеріал, який постійно поповнюється, дозволяють отримати автору важливу інформацію про генезис середньовічних міст України, визначити особливості, шляхи й хронологічні рамки їхнього розвитку.

Про Володимир в 2010 р. С.В. Терським вже надрукована солідна монографія, присвячена цьому місту - «Княже місто Володимир». в якій подано детальний опис виявлених за майже 150-річний період його вивчення археологічних об'єктів: оборонні укріплення, храми, житлові та господарські будівлі, поховання. Однак процес дослідження Володимира не зупинився. Протягом останніх десяти-п'ятнадцяти років у місті проводилися рятівні археологічні дослідження, які доповнюють наше уявлення про цей стародавній центр Західного Побужжя.

У рецензованій новій монографії С.В. Терського значно розширений хронологічний діапазон дослідження, - від періоду заселення району Володимира стародавніми людьми до кінця XVIII століття - періоду занепаду Речі Посполитої та входження Західної Волині до складу Російської імперії.

Таким чином, у монографії розглянуто суцільну історичну канву, яка показує особливості розвитку великого міського центру Східної Свропи протягом понад тисячу років: від племінного центру волинян і до ранньомодерного міста.

Як відомо, розробка науково обгрунтованої типології давньоукраїнських поселень в цілому і міст зокрема, входить у число актуальних завдань історіографії. Від іiі успішного вирішення багато в чому залежить дослідження загальних закономірностей історичного розвитку Київської Русі. Саме вивчення археологічних матеріалів, які містять цінні дані для вирішення широкого кола питань, пов'язаних з проблемою типології, структури, стратегічного значення міст Галицько-Волинської держави, дозволяє суттєво поглибити знання про ранні етапи Української державності.

У цьому контексті монографія Терського С.В. $є$ досить актуальною і складає певний науковий інтерес, оскільки присвячена одному 3 найдавніших міст Заходу України, центру князівства - Володимиру. Важливість дослідження цього міста полягає в тому, що на його прикладі ми можемо простежити i 
вивчити безперервний розвиток стародавніх міст України, оскільки середньовічний Володимир не занепав у результаті навали монголо-татар, а продовжував розвиватися як урбанізаційний центр Волині.

Заслугою автора $є$ не лише подальше введення в науковий обіг значних археологічних матеріалів, здобутих в результаті власних польових розвідок і розкопок, але й прискіпливий аналіз недавно виявлених та обтічно опублікованих знахідок інших археологічних експедицій, які завдяки уважному поглядові досвідченого дослідника свідчать про маловідомі факти суспільного та духовного життя мешканців Володимира.

Відтак, автором повторно проаналізований значний археологічний матеріал, здобутий, насамперед, у два останні десятиліття. Саме він складає джерельну базу рецензованої монографії. Таким чином, вперше для міста Волинської землі проведене спеціальне дослідження, яке охоплює проблеми появи, ранніх етапів розвитку східнослов'янських племінних центрів за матеріалами конкретного регіону, з широким використанням археологічних, топонімічних та писемних джерел, які вдало взаємодоповнюються.

Такий підхід дав можливість 3 більшою повнотою висвітлити, а в окремих випадках підняти і розглянути по-новому ряд питань, пов'язаних $з$ розвитком господарства та побуту міста протягом тривалого хронологічного відрізка часу в понад тисячу років.

У першому розділі «Історія досліджень та стан джерельної бази археології Володимира та околиць» автор характеризує бібліографію проблеми, показує історію археологічних досліджень, аналізує наявні музейні збірки артефактів. Тут Терський С.В. велику увагу приділяє суб'єктивним соціально-економічним i політичним причинам, які перешкоджали ефективному дослідженню археології міста.

У другому розділі «Археологія Володимирщини доісторичного періоду» за археологічними джерелами описана історія населення басейну р. Луги від кам'яної до ранньослов'янської доби. Особлива увага приділяється початкам формування протоміської агломерації.

У третьому розділі «Міська археологія X - XIV ст.» Терський С.В. подає новий погляд на територіально-топографічну структуру міста, його планіграфію. Тут також детально аналізується типологія храмової та житлової забудови. 
Значна увага у розділі приділяється соціально-економічній історії міста Княжої доби. Досить грунтовно автор аналізує суспільні функції політичного центру міста - дитинця.

Важливим, на наш погляд, $є$ розгляд інших структурних елементів стародавнього міста. Серед них: середмістя, передмістя та приміська інфраструктура. При цьому кожний структурний елемент дослідник розглядає системно, всебічно, із залученням характеристики археологічних об'єктів, карт міста другої половини XIX ст.

Крім того, автор на основі залучення та порівняння археологічних матеріалів та актових писемних джерел XVI-XVII ст. детально розглядає етапи заселення середмістя, еволюцію систем укріплень і забудови території, порівнює призначення й виводить головні ознаки міського та приміського ринків. На основі археологічних розкопок автор приходить до досить цікавого висновку, що місто в другій половині XIV ст. повертається до забудови класичними садибами, а забудова, характерна для західноєвропейських міст цього періоду, зберігається, переважно, в районі Ринкового майдану.

Важливим $є$ висновок про локалізацію згаданого в літописі храму св. Димитрія в межах Малого Окольного города Володимира. Святий воїн Димитрій відомий як покровитель дружинників, що переважно традиційно населяли цю частину міста.

Досить детально автор характеризує торгівлю міста, простежуючи іiі еволюцію, починаючи 3 X ст. Досліджуючи напрямки торговельних інтересів міста, Терський С.В. характеризує різноманітні категорії імпортних речей, скарби, широко залучаючи при цьому дані писемних документів. Про значення міста в торговельній політиці Галицько-Волинської держави та раннього Великого князівства Литовського свідчать дані про те, що у другій половині XIII - XIV ст. у Володимирі міг існувати державний монетний двір, де карбували монети цього князівства.

Грунтовно (хоча можна було б і більш детально) автор характеризує військову справу населення цього важливого волинського міста. Серед зброї він виділяє мечі, хоча хронологічної та типологічної класифікації не проводить. Тут же згадані шаблі, вістря списів, стріл, болти самострілів. На цьому тлі більш детально характеризуються сокири. Автор знаходить широкі аналогії виявленим предметам озброєння та обладунку воїнів на інших давньоукраїнських землях 
Досить багатою була духовна культура населення Володимира. Терський С.В. на основі широкого залучення археологічного матеріалу показав еволюцію розвитку християнської культури в місті поряд з широкими залишками язичницьких вірувань серед місцевого населення. При цьому автор правильно констатує, що 3 розростанням вшир і вглиб християнства, язичницькі культові місця переносять за межі міста, а на їхніх місцях споруджуються християнські храми. Докладно автор розглядає й архаїчні обряди, які збереглися в побуті міщан.

Терський С.В. також детально характеризує християнську культову атрибутику, виявлену в місті, простежує значення впровадження християнства із поширенням грамотності серед міщан. Про це свідчать знахідки писал, графіті, печаток-малівдовул, підписних перснів-печаток. На думку автора монографії, Володимир був важливим центром книго- та іконописання. Це своє припущення автор підтверджує рядом аргументованих доказів стосовно володимирського походження т.зв. Добрилового Свангелія.

Важливим i iнформативним $є$ наступний розділ монографії «Археологія Володимира XV - XVIII ст.». При характеристиці житлового будівництва XVI - XVII ст. автор широко використовує дані писемних джерел. На нашу думку, в роботі при характеристиці забудови Ринку Володимира та різних типів міщанських житлових, господарських та виробничих споруд автору необхідно було б показати аналогії в інших містах ранньомодерної України. За умови практично повної відсутності розкопаних археологами ділянок цієї частини міста це дало б змогу простежити загальні принципи планування, способи спорудження, або ж вичленувати локальні, характерні лише для даного регіону способи будування й обладнання вищеназваних споруд.

Досить детально автор описує інтер'єр жител. Важливою ілюстрацією до цієї частини опису жител $є$ малюнки кахлів. Цікавим $є$ опис застосування брускової цегли у Володимирі, починаючи 3 XIII - XIV ст. Тут можна говорити про цегляне будівництво жител, яке було викликане потребами оборони та протипожежного захисту.

Цілком аргументованими виглядаю і заключні сторінки третього та четвертого розділів монографії, які висвітлюють значення Володимира в історії України та його міжнародні зв'язки. Терський С.В. на основі широкого залучення писемних джерел $\mathrm{i}$ 
документального матеріалу простежив формування суспільнокультурного обличчя міста, які, як зазначає автор, виходило за межі суто торговельних зв'язків. Він цілком слушно зауважує, що в силу географічного розташування Волині відносно Києва волинська знать завжди більше тяжіла до своїх західних сусідів $\mathrm{i}$ була в опозиції до центральної київської влади. Більшість князів 3 місцевої династії Рюриковичів була пов'язана родинними зв'язками 3 представниками феодальної верхівки країн Центральної Свропи.

Не менш важливі були зв'язки міста 3 країнами Сходу, Північного Причорномор'я, Золотою Ордою тощо. Це, в свою чергу, відобразилося на етнічному складі міщан.

У підсумках монографічного дослідження автор робить цілком переконливі висновки, що Володимир є типовим слов'янським містом, що виросло з племінного кореня, а його історія є важливою для реконструкції історії суспільства Княжої та Ранньомодерної доби.

На основі отриманого в результаті археологічних досліджень на території міста речового матеріалу можна простежити не тільки рівень матеріальної культури, зокрема, й військової, але й деякі елементи духовної культури давніх дружинників. Отримані матеріали 3 досліджень Володимира значно доповнюють нашу уяву про давньоукраїнські міста, їх складові частини, етапи їх розвитку, а також збагачують вітчизняну історичну науку новими неоцінимими археологічними джерелами, які у майбутньому допоможуть науковцям при вивченні давньоукраїнських міст періоду розвинутого середньовіччя та початку нової доби.

Монографія Терського С.В. залишає враження оригінального дослідження. Вона базується на значному фактичному матеріалі, який дозволяє зробити переконливі висновки 3 актуальних проблем історії досліджуваного регіону. Книга відзначається новизною матеріалів і актуальністю проблематики. Значно доповнюють монографію ілюстрації, в тому числі й кольорові.

Дослідження Терського С.В. має практичне значення. Одержані матеріали і висновки можуть бути використані при написанні узагальнюючих праць із стародавньої історії України, для характеристики періодів розвиненого та пізнього середньовіччя не тільки досліджуваного регіону, але й для всієї Української держави, при вивченні нормативних курсів «Історія України», військовоісторичних розвідок про оборонні споруди, історії зброї й історичного краєзнавства. 